Medicine Updates

Faculty of medicine

April 2021,volume 5, issue 5 https://muj.journals.ekb.eg

dean@med.psu.edu.eg

vice_dean_postgraduate@med.psu.edu.eg

DOI: 10.21608/muj.2021.63265.1043

Submitted: $15 / 2 / 2021$

Accepted : 17/2/2021

Pages:78- 95

\title{
"Implementation of quality tools
}

to improve infection control service

\section{In Tadamun Hospital in Portsaid city 2020/2021"}

\author{
Authors: \\ Eman Samir mostafa: Community Pharmacist \\ Moataz Mohsen selmi: Dentist At Ali Ben Abi Taleb Medical Care Center \\ Mohab Mahmoud ismaeel: Manager at Tenth of Ramadan Medical Care Unit \\ Ahmed elsayed abdelaal: Community Pharmacist \\ Mohamed Mahmoud kotb: Community Pharmacist \\ Mennatullah bahaa elboghdady: Community Pharmacist \\ Wegdan hamdy: Pharmacist at Chest Hospital \\ Aya ahmed awad marey: Pharmacist at Chest Hospital \\ Eman Muhammad Elbadry: Qualified Nurse, Quality Specialist at Alhayah \\ Portfuad Hospital
}




\section{ABSTRACT}

A healthcare-associated infection (nosocomial infection) is an infection that is acquired in any health care facility. This infection can be acquired in hospital, nursing home, diagnostic laboratory,outpatient clinic, rehabilitation facility or other clinical settings. Infection is spread to the patient in the health care facility in different ways.

Medical staff also spread infection, beside contaminated equipment,air droplets or bed linens. The infection can be developed from the outside environment, staff that may be infected or another infected patient, or in some cases, the source of the infection cannot be specified. In some cases the microorganism originates from the patient's skin microbiota, becoming opportunistic after surgery or other procedures that compromise the protective skin barrier. Although the patient may have contracted the infection from their own skin, the infection is still considered nosocomial because it develops in the health care facility ${ }^{(2)}$

Our aim is to reduce risk of health care acquired infections in (Tadamun Hospital) hospital to ensure patient safety. The implementation of quality tools like brain storming, fish bone diagram and chek list help us to identify the most influential cause of hospital acquired infection and to create an action plan for problem solving and continuous improvement.

\section{Key words (Hospital acquired infection - Quality}

Tools- Infection control)

\section{Introduction}

Infection control is a scientific process and practical solution intended to prevent harm caused by infection to patients and health staff. Usually infection control 
program is risk based, so risk assessment is required to instantly identify and proactively measure possible infection risks between individuals and in the environment. After that, solutions will be tailored by developing appropriate standards and procedures, beside proper staff education. ${ }^{(4)}$

Infection control programs are based on current scientific knowledge, the national guidelines, accepted international practice guidelines (CDC, IFIC APIC,), and applicable policies and standards. Hospital acquired infections are a major cause of morbidity and mortality between patients in health care facility ${ }^{(4)}$

The mortality rate related to infections was $38.4 \%$, and it was classified as a contributing factor to deaths in $87.1 \%$ of death cases. The correlation between hospital acquired infections and death was statistically considerable between clinical patients $(41.3 \%)$ presenting comorbidities related to the diagnosis $(55.8 \%)$, cardiovascular infection (62.2\%), developing sepsis (69.0\%), pneumonia (48.9\%), , as well as patients who had been colonized (45.2\%) and infected (44.7\%) by multidrug resistance microorganisms. ${ }^{(1)}$

\section{Aim of the study}

The purpose of this study is to protect patients and members of the hospital team from transmission of infection.

\section{Methodology}

\section{Quality tools used (TQM TOOLS):}

FOCUS - PDCA

Brain storming 
Cause \&effect diagram (fish bone analysis)

Check list

Action plan

FOCUS - PDCA

FOCUS PDCA is a management tool, used to improve processes, developed in the healthcare industry, formed by the Hospital Corporation of America (HCA), it is a systematic process improvement method. By FOCUS PDCA, we can know how the process is performed to meet customer needs and expectations, then plan and test process changes. FOCUS PDCA is an extension of the Deming or Shewhart Cycle which consist of Plan-Do-Check-Act. This tool consist of five-part plan:

F. Find the process we want to improve

O. Organization of the process improvement

C. Clarify current status of the process

U. Understanding the source of variation of the process

S. Select the process improvement

Brainstorming, this technique used critical thinking by group members to find solutions to a certain problem. It is an instructural strategy that stimulate individual to use creativity in thinking.

Techniques that Facilitate discussion in Brain Storming:

1) Ask open questions.

2) Summarize discussion points and draw conclusions. 


\section{Fishbone diagram or cause and effect diagram}

It is a diagram that helps the leaders to find the causes of problems and defects.

This diagram looks like a fish skeleton in which the head means the problem and the bones means the causes of the problem which have been identified. Once all the causes of the problem have been specified, leaders then search to find solutions to avoid the repetition of the problem.

Check list to determine causes of health care acquired infections; The check list is one of the main tools of quality control which created by Dr. Kaoru Ishikawa. check sheet is characterized by that data is recorded by making marks ("checks") on it. check list is divided into regions, and marks made in different regions have different significance ${ }^{(5)}$.

\section{$\underline{\text { Action plan to reduce HAIs risks }}$}

It should be clear.

It should be realistic.

It should doable.

Has timeline (starting and ending time).

It must be complete 


\section{Results}

\section{Tool one FOCUS-PDCA:}

\section{F : Find What Is The Process}

- There is an opportunity to decrease nosocomial infection in the hospital

- Reduction of infection rate is one of the International Patient Safety Goal.

- We have 1 patient with surgical site infection in August,7 patients developed pneumonia within the last 5 months due to ventilator,5 patients developed infection at CVP site within the last 4 months, 4 patients have urinary tract infection within the last 2 months.

1. About 1 in 10 patients in health care facility will acquire an infection after admission (Graves, N., 2004).

2. Brainstorming done for selection of project

3. Prioritizing matrix done to choose the project

\section{0 : Organize The Team}

1. QM Director( Team Leader)

2. Quality Coordinator

3. Nursing Supervisor

4. Safety

5. Maintenance department

6. Housekeeping Supervisor

7. Infection control member

8. Patient safety Coordinator 


\section{PRIORITIZING MATRIX}

\begin{tabular}{|c|c|c|c|c|c|c|c|}
\hline $\begin{array}{c}\text { PROJEC } \\
\text { T }\end{array}$ & $\begin{array}{c}\text { High } \\
\text { risk }\end{array}$ & $\begin{array}{c}\text { High } \\
\text { volume }\end{array}$ & $\begin{array}{c}\text { Staff } \\
\text { satisfactio } \\
\text { n }\end{array}$ & $\begin{array}{c}\text { Patient } \\
\text { satisfac } \\
\text { tion }\end{array}$ & $\begin{array}{c}\text { Low } \\
\text { cost }\end{array}$ & $\begin{array}{c}\text { Less } \\
\text { time }\end{array}$ & Total \\
\hline $\begin{array}{c}\text { Hospital } \\
\text { acquired } \\
\text { infection }\end{array}$ & 66 & 61 & 9 & 61 & 7 & 6 & 58 \\
\hline $\begin{array}{c}\text { Reduction } \\
\text { of patient } \\
\text { fall down }\end{array}$ & 9 & 7 & 9 & 10 & 8 & 7 & 50 \\
\hline $\begin{array}{c}\text { Improve } \\
\text { VTE } \\
\text { assessmen } \\
\text { t }\end{array}$ & 8 & 5 & 6 & 7 & 7 & 7 & 40 \\
\hline $\begin{array}{c}\text { Reduction } \\
\text { of } \\
\text { Improper } \\
\begin{array}{c}\text { Patient } \\
\text { identificati } \\
\text { on on lab } \\
\text { reports }\end{array}\end{array}$ & 9 & 5 & 5 & 7 & 7 & 5 & 41 \\
\hline
\end{tabular}

So we select the project named Implementation of quality tools to improve infection control service

\section{C: Clarify The Actual Flow}

To clarify the current status about the process, the following steps were done:

1. Data was collected from the indicators over last 6 months showed 1 patient with surgical site infection in August, 7 patients developed pneumonia within the last 5 months due to ventilator, 5 patients developed infection at CVP site within the last 4 months, 4 patients have urinary tract infection within the last 2 months.

2. Improper implementation of infection control policy \& procedures during this period.

3. Brainstorming done about the causes of hospital acquired infection. 


\section{U: Understand Major Causes For Variation. Data Need To Be Collected And Reflect Causes}

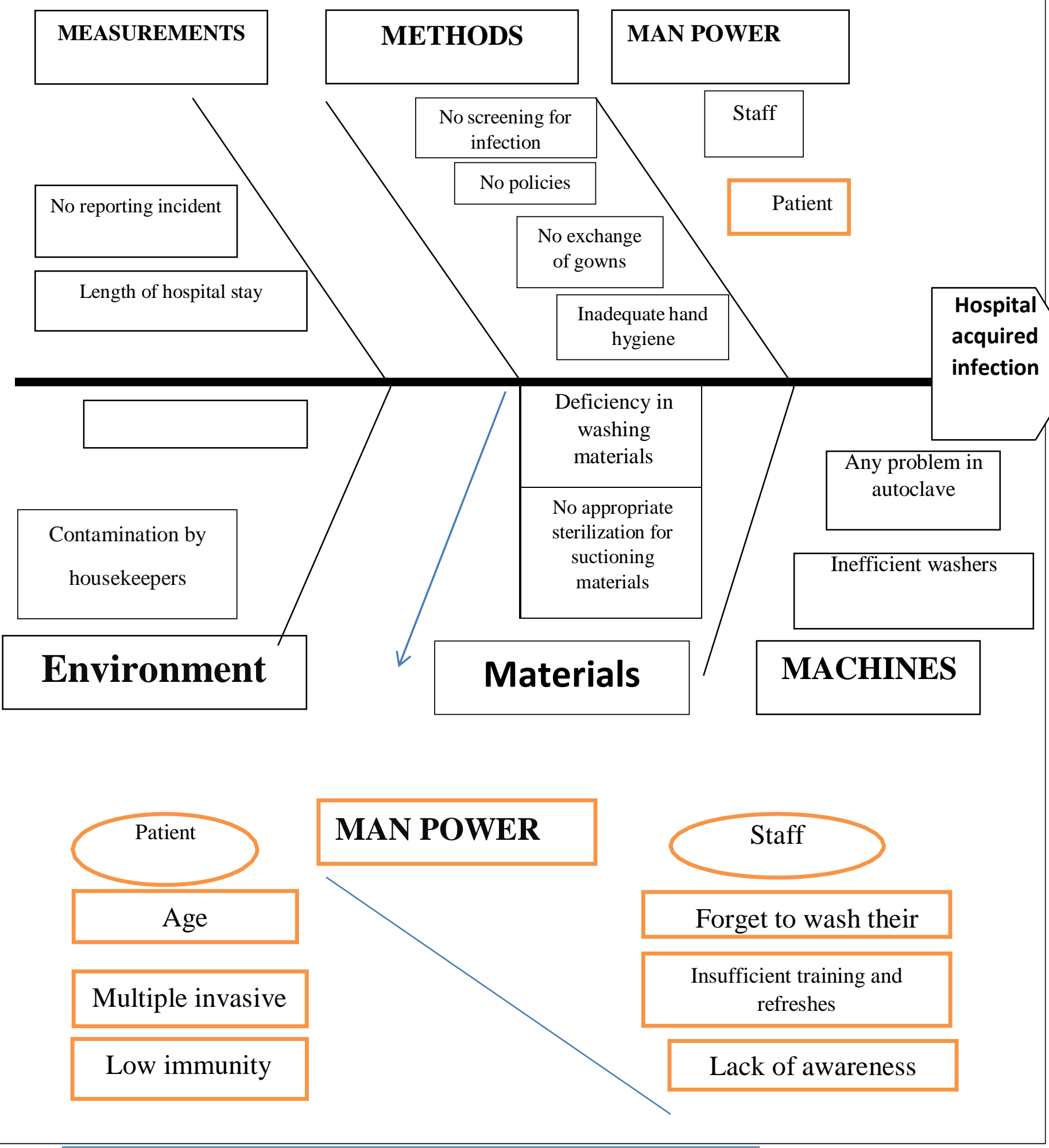




\section{Tool used : Fishbone}

\section{S: Select Actions That Need To Be Taken To Improve The Process}

This is a list of recommendations to decrease the incidence of nosocomial infection.

The process is reporting.

1. To implement infection control policy \& procedures.

2. Develop education $\&$ training session for house keepers.

3. Improve communication between medical staff and infection control team for reporting for any infection occurs.

\begin{tabular}{|c|c|c|c|c|c|c|}
\hline \multicolumn{7}{|c|}{ P:Put Plan To Do Actions } \\
\hline \multicolumn{7}{|c|}{ The tool used is Gantt Chart } \\
\hline & Solution & Method & Target & Time frame & Responsible & Resource \\
\hline 1 & $\begin{array}{l}\text { Implementation } \\
\text { of infection } \\
\text { control policy \& } \\
\text { procedures }\end{array}$ & $\begin{array}{l}\text { Meeting, } \\
\text { Lectures, } \\
\text { Observation, } \\
\text { Checking } \\
\text { Assessment } \\
\text { Form }\end{array}$ & $100 \%$ & week & $\begin{array}{l}\text { Nursing } \\
\text { Director }\end{array}$ & \\
\hline 2 & $\begin{array}{l}\text { Housekeeping } \\
\text { Training }\end{array}$ & $\begin{array}{l}\text { Lectures, } \\
\text { workshops }\end{array}$ & $100 \%$ & week & $\begin{array}{l}\text { Housekeepin } \\
\text { g Supervisor }\end{array}$ & \\
\hline 3 & $\begin{array}{l}\text { Handwashing } \\
\text { supplies }\end{array}$ & Purchase & $100 \%$ & week & $\begin{array}{l}\text { Property } \\
\text { Control }\end{array}$ & \\
\hline 5 & $\begin{array}{l}\text { Develop policy } \\
\& \text { procedures } \\
\text { for follow up } \\
\text { patient acquired } \\
\text { infection }\end{array}$ & & $100 \%$ & week & $\begin{array}{l}\text { Infection } \\
\text { control } \\
\text { director }\end{array}$ & \\
\hline
\end{tabular}




\section{D : Do The Improvement, Collect \& Analyze Data}

1. Policy \& procedures for infection control is done $\&$ implemented

2. Handwashing materials now available

3. Training for housekeeper done

4. Policy for follow up for patient infection done

5. Improvement in reporting system.(now we are under reporting)

\section{C: Check For The Results}

1. Monitoring for implementation of the policy for infection control and patient assessment

2. Last month no report for patient infection

3. Encourage the reporting

A : Act ( Make Awareness For New Modified Process, Revise Policies

- Encourage reporting for all health care providers

- Analyze the cause of incident (infection) to be done by the Quality nurse.

- Auditing the policy to be done by the Quality nurse.

- Training and education for nurses in nursing education department.

\section{Tool two brainstorming}

\begin{tabular}{|c|l|}
\hline \multirow{2}{*}{$\begin{array}{c}\text { Using brain } \\
\text { storming tool we } \\
\text { determine the } \\
\text { cause of } \\
\text { infection }\end{array}$} & $\begin{array}{l}\text { The quarantine department shares the same floor with other departments like } \\
\text { Endoscopy department. }\end{array}$ \\
\cline { 2 - 2 } & $\begin{array}{l}\text { The patients use the same door to get in and out } \\
\text { admitted to the hospital include; patients with diabetes- elderly patients - } \\
\text { patients with cancer- patients receive immunosuppressive drugs }\end{array}$ \\
\hline
\end{tabular}




\begin{tabular}{|l|l|}
\hline & \begin{tabular}{l} 
Lack of reporting for all medical staff. \\
\cline { 2 - 3 }
\end{tabular} \\
$\begin{array}{l}\text { Lack of training of medical staff on how to properly apply quality } \\
\text { standards }\end{array}$ \\
\hline
\end{tabular}

\section{Tool three Action plans}

\begin{tabular}{|c|c|c|c|c|}
\hline Goals & Activities & $\begin{array}{l}\text { Responsible } \\
\text { person }\end{array}$ & Time & Resources \\
\hline \multirow{3}{*}{$\begin{array}{l}\text { protect patients } \\
\text { and members of } \\
\text { the hospital } \\
\text { team from } \\
\text { transmission of } \\
\text { infection. }\end{array}$} & $\begin{array}{l}\text { 1/activate } \\
\text { policies And } \\
\text { standards }\end{array}$ & $\begin{array}{l}\text { Medical } \\
\text { director }\end{array}$ & $\begin{array}{c}0106 / 3 / 6 \\
\text { To } \\
0106 / 3 / 65\end{array}$ & $\begin{array}{l}\text { Official declaim } \\
\quad \text { (regulatory) }\end{array}$ \\
\hline & $\begin{array}{l}\text { Prepare and print } \\
\text { documentation } \\
\text { form }\end{array}$ & Quality manager & $\begin{array}{c}\text { 0106/3/66 } \\
\text { To } \\
0106 / 3 / 25\end{array}$ & $\begin{array}{c}\text { Documentation } \\
\text { material } \\
\text { (financial) }\end{array}$ \\
\hline & $\begin{array}{l}\text { Medical team } \\
\text { training to apply } \\
\text { the standards }\end{array}$ & $\begin{array}{c}\text { Medical director } \\
\text { Nurse head }\end{array}$ & $\begin{array}{c}0106 / 3 / 06 \\
\text { To } \\
0106 / 4 / 2\end{array}$ & $\begin{array}{l}\text { Man power } \\
\text { ( human R ) }\end{array}$ \\
\hline
\end{tabular}




\section{Tool four check list}

\begin{tabular}{|c|c|c|c|c|}
\hline$\#$ & Point of measurement & done & $\begin{array}{l}\text { Not } \\
\text { done }\end{array}$ & remarks \\
\hline 1 & $\begin{array}{l}\text { Hand hvgiene } \\
\text { The hospital develops written policies and } \\
\text { procedures on appropriate hand hygiene }\end{array}$ & & & \\
\hline 2 & $\begin{array}{l}\text { Availability of alcohol gel hand agent and } \\
\text { gloves in patients care units }\end{array}$ & & & \\
\hline 3 & $\begin{array}{l}\text { Hand are washed under warm running } \\
\text { water for at least } 40-60 \text { seconds }\end{array}$ & & & \\
\hline 4 & $\begin{array}{l}\text { Hand washing poster ,tissue and baskets are } \\
\text { present }\end{array}$ & & & \\
\hline 5 & $\begin{array}{l}\text { Staff finger nails are clean ,short,jewellery } \\
\text { is not worn and artificial nails are not worn } \\
\text { when having direct contact with patients }\end{array}$ & & & \\
\hline 6 & $\begin{array}{l}\text { Clinical staff uses appropriate technique } \\
\text { when cleaning their hands }\end{array}$ & & & \\
\hline 7 & $\begin{array}{l}\text { Hand hygiene is done before contact with } \\
\text { patient or immediate care environment }\end{array}$ & & & \\
\hline 8 & $\begin{array}{l}\text { Hand wash is done after touching the } \\
\text { patient or immediate environment after } \\
\text { removing gloves }\end{array}$ & & & \\
\hline 9 & $\begin{array}{l}\text { Hand wash before and after procedure } \\
\text { performing an aseptic task }\end{array}$ & & & \\
\hline 10 & $\begin{array}{l}\text { Hand wash after contact with body fluids, } \\
\text { blood, or contaminated surfaces }\end{array}$ & & & \\
\hline 11 & $\begin{array}{l}\text { Hand wash after hands move from a } \\
\text { contaminated body to a clean body during } \\
\text { patient treatment. }\end{array}$ & & & \\
\hline 12 & $\begin{array}{l}\text { Clinical staff performs hand wash before } \\
\text { wearing gloves when inserting a central } \\
\text { venous catheter }\end{array}$ & & & \\
\hline 13 & $\begin{array}{l}\text { Clinical staff uses water and soap when } \\
\text { hands are obviously soiled or where } \\
\text { contamination is suspected }\end{array}$ & & & \\
\hline 14 & Patient safety committee meeting & & & \\
\hline
\end{tabular}




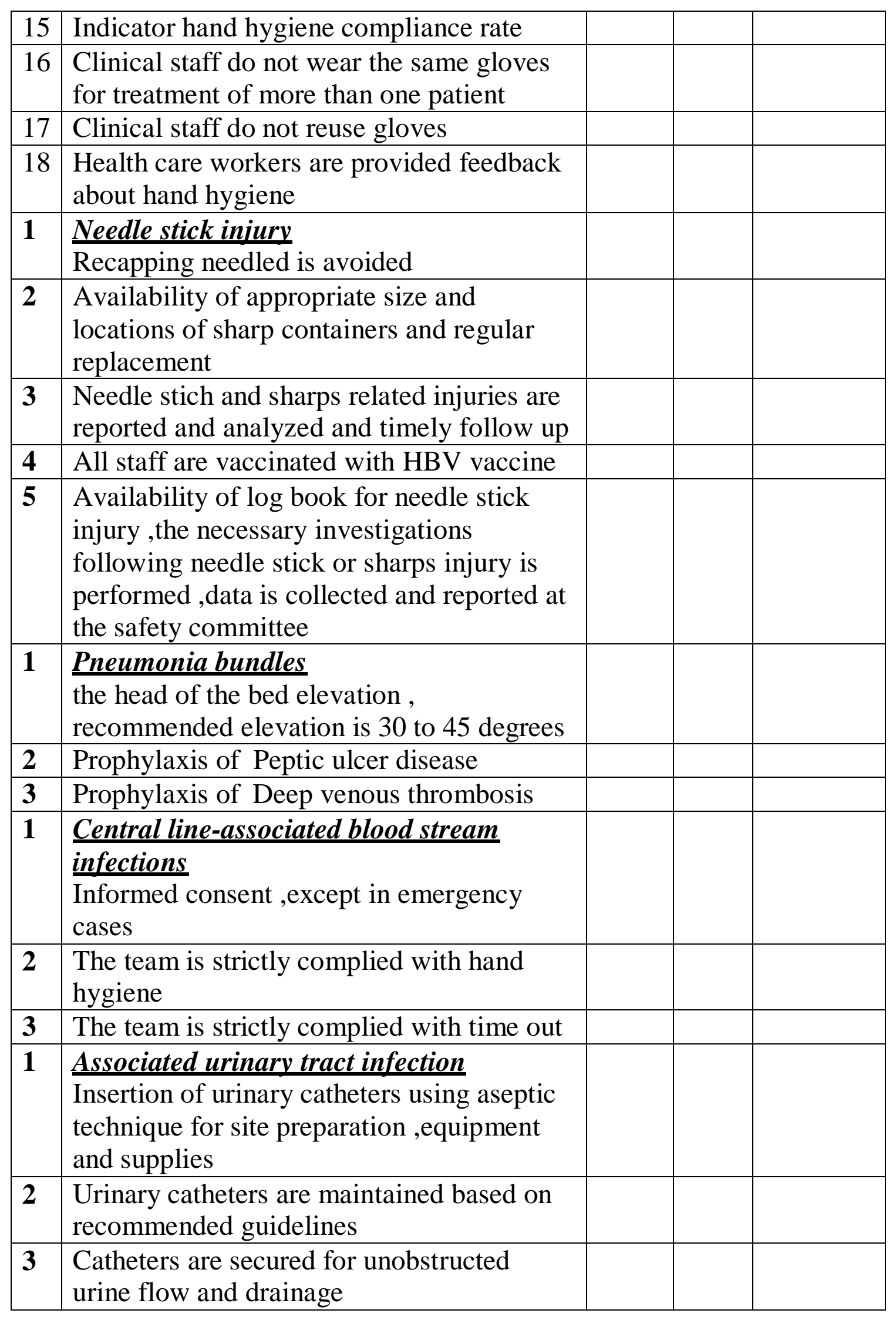




\begin{tabular}{|l|l|l|l|l|}
\hline $\mathbf{4}$ & $\begin{array}{l}\text { The sterility of the urine collection system } \\
\text { is maintained }\end{array}$ & & & \\
\hline $\mathbf{5}$ & $\begin{array}{l}\text { Urinary catheter necessity is reviewed daily } \\
\text { and unnecessary urinary catheters are } \\
\text { removed promptly }\end{array}$ & & & \\
\hline $\mathbf{1}$ & $\begin{array}{l}\text { Surgical site prevention } \\
\text { Surgical site infection rate is measured and } \\
\text { known }\end{array}$ & $\begin{array}{l}\text { Positive pressure ventilation in OR is } \\
\text { maintained with at least 15 air changes / hr }\end{array}$ & & \\
\hline $\mathbf{3}$ & OR doors are kept closed & & & \\
\hline $\mathbf{4}$ & Sterile instruments are used & & \\
\hline $\mathbf{5}$ & $\begin{array}{l}\text { Surgeons/ staff clean hands with } \\
\text { appropriate agents and methods }\end{array}$ & & & \\
\hline $\mathbf{6}$ & $\begin{array}{l}\text { Surgeons/ staff wear mask, sterile double } \\
\text { glove ,cover hair }\end{array}$ & & & \\
\hline $\mathbf{7}$ & $\begin{array}{l}\text { Surgeons/ staff maintain short nails } \\
\text { remove artificial nails }\end{array}$ & & & \\
\hline $\mathbf{8}$ & $\begin{array}{l}\text { Skin area is prepared with appropriate } \\
\text { agent }\end{array}$ & & & \\
\hline
\end{tabular}

\section{Discussion}

From Result (brainstorming), it is clear that there are many causes for nosocomial infection. The most common causes are urinary tract infection (UTI), surgical site infection (SSI), pneumonia, and bloodstream infection (BSI) ${ }^{(7) .}$

We describe the results of, CAUSE\&EFFCTS DIAGRAM which show that there is some factors which may increase the incidence of infection, as patient age, diagnosis, invasive procedures or antibiotic resistance according to man power. Another cause according to measurements is length of hospital stay; when the patient stays longer in the hospital, he is more susceptible for infection. ${ }^{(6)}$ 
From result (fishbone diagram), it is obvious that the main role of immaculate environment (according to environmental factors), the importance of immaculate environment may remain estimated.

Cleaning with, or without, disinfectants, significantly reduce infection rates for individuals. Unluckily, cleaning is commonly performed as part of a whole infection control process and the importance of cleaning as a single intervention remains debatable ${ }^{(3)}$.

Recent studies has shown that hand-touch sites are often contaminated by hospital pathogens, which are then delivered to patients and workers on hands (according to man power). ${ }^{(3)}$

By prioritizing the cleaning of these sites, this maybe assistant factor to the current studies with hand hygiene, since hand-touch sites comprise the less well-studied side of the hand-touch site equation

In addition, using proposed standards for hospital hygiene give us evidence that cleaning is a cost-effective intervention for controlling nosocomial infection.(according to methods) $)^{(3)}$

\section{Conclusion}

\section{From this project we conclude the following points:}

- By applying quality tools in this study and determination of root causes we can decrease risk of HAIs.

- As part of infection control program, health care organization should improve, implement and document effective and efficient policies and standards for staff health and safety, in addition to strategies to prevent risk of exposure to 
infection hazards; and implement healthcare staff immunization programs for infectious agents they may encounter in the course of their duties.

- Nurses should know how to prevent the transmission of infection among patients during their hospital stay.

-Proper use of hand wash and personal protective equipment is very important to reduce the risk of transmission of infection to patients.

- Infection control practices have been proven to prevent repeated transmissions that contribute to an outbreak situation among multiple patients.

\section{Recommendations}

\section{From This Project we recommend the following points}

- Implementation of infection control culture in healthcare organization according to policies, guidelines, and protocols.

- Implementation of quality tools to improve infection infection control service; it should be valid and reliable tools.

- It should increase Training and education for nurses in nursing education department.

- Data collection about economic impact of Hospital acquired infections.

- Improve health care facility information systems for review of appropriateness of infection control-related care based on patient diagnosis.

- specify components of infection control programs in health care facility that are effective and efficient in reducing rates of infection. 
- Develop multidisciplinary team to improve quality control programs.

\section{Acknowledgement}

First of all, thanks to ALLAH, the most gracious, most merciful. For guiding us and giving us strength to complete this work.

We would like to thank the administration and staff in EL- TADAMON

HOSPITAL for their unconditional support and help.

\section{List of Abbreviations}

HAIs: Healthcare Associated Infections

CDC: Centers for Disease Control and prevention

APIC: Associations for professionals in Infection Control and Epidemiology

IFIC: The International Federation of Infection Control

TQM: Total Quality Management

HCA: Hospital Corporation of America

\section{REFERENCES}

(1) Allegranzi, B., Gayet-Ageron, A., Damani, N., Bengaly, L., McLaws, M. L., Moro, M. L., ... \& Pittet, D. (2013). Global implementation of WHO's multimodal strategy for improvement of hand hygiene: a quasi-experimental study. The Lancet infectious diseases, 13(10), 843-851.

(2)Bamberg, W., Heinrichs, G., Nyberg, C., \& Parker, R. PREVENTION OF HOSPITAL ACQUIRED INFECTIONS. 
(3) Dancer, S. J. (2009). The role of environmental cleaning in the control of hospital-acquired infection. Journal of hospital Infection, 73(4), 378-385.

(4) GAHAR handbook for primary healthcare standards, 2019, page 192.

(5)Hinde, R. A. (1973). On the design of check-sheets. Primates, 14(4), 393-406.

(6) Orsi, G. B., Scorzolini, L., Franchi, C., Mondillo, V., Rosa, G., \& Venditti, M. (2006). Hospital-acquired infection surveillance in a neurosurgical intensive care unit. Journal of Hospital Infection, 64(1), 23-29.

(7) Weinstein, R. A., Gaynes, R., Edwards, J. R., \& National Nosocomial Infections Surveillance System. (2005). Overview of nosocomial infections caused by gram-negative bacilli. Clinical infectious diseases, 41(6), 848-854. 